\title{
Constraints Faced by the Vegetable Growers in Marketing of Vegetables and Suggestions to Overcome these Constraints
}

\author{
S.H. More; J.R. Kadam; S.K. Deshmukh; P.M. Zagade \\ Department of Extension Education, College of Agriculture, Dapoli, Ratnagiri- 415712, Maharashtra \\ DOI: 10.47856/ijaast.2021.v08i1.004
}

\begin{abstract}
This study was conducted in Dahanu and Palghar tahasils of Palghar district of Konkan region. The sample constituted of 120 vegetable growers from 10 villages. The respondents were interviewed with the help of specially designed schedule. The specific aspectwise study of marketing behaviour revealed the constraints such as fluctuation in market price, high commission charges, High cost of transportation, absence of storage facilities, lack of market information, Inadequate physical facilities in the market, prolonged transaction, faulty system of weighment, no grading facilities, illegal deduction while selling, lack of processing facilities and markets are far away are faced by the vegetable growers of the Palghar district and suggestions like providing access to market information, display of prices at each market place, fixing minimum price for the produce, fixing minimum labour charges, more procurement at nearby places, providing lodging and boarding facilities at market place, establishing separate market for major produce were provided to overcome the constraints faced.

Keywords: Constraints, Suggestions, Vegetable, Growers, Palghar, Dahanu
\end{abstract}

\section{INTRODUCTION}

India is principally a vegetarian country and second largest producer of vegetables, next to China. Vegetables form the most nutritive menu of man and tone up his energy and vigour. Regular and balanced use of vegetables provides the most essential health building and protecting substances such as vitamins and minerals. The nutrients in the vegetables overcome the common disorders like anemia, deficiency disorders and other aliments in human body and they form a vital part of human diet. For balanced diet an adult needs about 280 grams of vegetables per day of which about 85 grams should comprise of root vegetables, 110 grams of leafy vegetables and 85 grams of other kinds of vegetables. But the national average consumption is less than 81 grams. Present marketing system of vegetables is inadequate. The problems of vegetable growers are numerous. However, lack of market infrastructure, unavailability of timely market information and price fluctuation seem to be the major bottleneck in the sustained development of vegetable production and its marketing. Presently, development of marketing infrastructure to solve the problems of vegetable growers in rural areas is the primary concern of the government. Hence, efforts are needed to identify the specific problems related to vegetable marketing and also there is a need to improve market system for vegetables. Hence, an attempt has been made in this study to find out the various marketing practices followed and problems faced by vegetable growers in this region. 


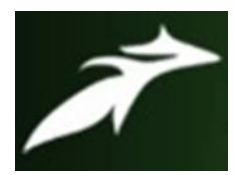

S.H. More et al, International Journal of Advances in Agricultural Science and Technology,

Vol.8 Issue.1, January-2021, pg. 29-32

ISSN: 2348-1358

Impact Factor: 6.057

NAAS Rating: 3.77

\section{OBJECTIVE}

To know the constraints faced by the vegetable growers in marketing of vegetables and suggestions to overcome these constraints.

\section{METHODOLOGY}

The study was conducted in Palghar district form Konkan region of Maharashtra state using the Ex-post facto research design. Data was collected by personally interviewing 120 vegetable growers with the help of specially designed interview schedule. Ten personal and socio-economic characteristics of the vegetable growers were selected as independent variables and these were measured with the help of available instruments and specially developed schedules, wherever needed. Statistical tools such as frequency, percentage, mean and standard deviation were used for grouping the data.

\section{RESULT AND DISCUSSION}

The present study accessed the constraints that are experienced by the vegetable growers in the marketing of vegetables and suggestions to overcome these constraints.

Table 1. Constraints faced by the vegetable growers in marketing of vegetables.

\begin{tabular}{|c|c|c|c|}
\hline \multirow[t]{2}{*}{ Sl. No. } & \multirow[t]{2}{*}{ Problems } & \multicolumn{2}{|c|}{ Respondents $=120$} \\
\hline & & Number & Percentage \\
\hline 1. & Fluctuation in market price & 120 & 100.00 \\
\hline 2. & High commission charges & 108 & 90.00 \\
\hline 3. & High cost of transportation & 102 & 85.00 \\
\hline 4. & Absence of storage facilities & 90 & 75.00 \\
\hline 5. & Lack of market information & 72 & 60.00 \\
\hline 6. & Inadequate physical facilities in the market & 65 & 54.17 \\
\hline 7. & Prolonged transaction & 60 & 50.00 \\
\hline 8. & Faulty system of weighment & 56 & 46.67 \\
\hline 9. & No grading facilities & 41 & 34.17 \\
\hline 10. & Illegal deduction while selling & 29 & 24.17 \\
\hline 11. & Lack of processing facilities & 26 & 21.66 \\
\hline 12. & Markets are far away & 23 & 19.17 \\
\hline
\end{tabular}

From the above table it is revealed that fluctuation in the market price was the major problem (100.00 per cent), followed by high commission charges (90.00 per cent) and high cost of transportation ( 85.00 per cent). While absence of storage facilities (75.00 per cent), lack of market information (60.00 per cent), inadequate physical facilities in the markets (54.17 per cent), prolonged transaction (50.00 per cent), faulty system of weighment (46.67 per cent), no grading facilities (34.17 per cent), illegal deduction while selling (24.17 per 


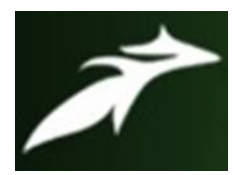

S.H. More et al, International Journal of Advances in Agricultural Science and Technology,

Vol.8 Issue.1, January-2021, pg. 29-32

ISSN: 2348-1358

Impact Factor: 6.057

NAAS Rating: 3.77

cent), lack of processing facilities (21.66 per cent), markets are far away (19.17 per cent) were the constraints reported by the vegetable growers in marketing of vegetables.

Table 2. Suggestions of vegetable growers to overcome marketing problem

\begin{tabular}{|l|l|l|l|}
\hline Sl. No. & \multicolumn{1}{|c|}{ Suggestions } & \multicolumn{2}{c|}{ Respondents $=120$} \\
\cline { 3 - 4 } & & \multicolumn{1}{c|}{ Number } & Percentage \\
\hline 1. & Providing access to market information & 115 & 95.83 \\
\hline 2. & Display of prices at each market place & 106 & 88.33 \\
\hline 3. & Fixing minimum price for the produce & 102 & 85.00 \\
\hline 4. & Fixing minimum labour charges & 90 & 75.00 \\
\hline 5. & More procurement at nearby places & 85 & 70.83 \\
\hline 6. & Providing lodging and boarding facilities at market place & 65 & 54.17 \\
\hline 7. & Establishing separate market for major produce & 56 & 46.67 \\
\hline
\end{tabular}

The contents from Table 2 indicates that majority of the respondents (95.83 per cent) suggested for providing access to market information, 88.33 per cent suggested to display the prices at each market place whereas, 85.00 per cent suggested for fixing minimum price for the produce whereas, followed by fixing minimum labour charges (75.00 per cent), providing concession in transportation charges ( 72.50 per cent), procurement at nearby places $(70.83$ per cent), providing loading and boarding facilities at market places (54.17 per cent) and establishing separate markets for their major produce (35.00 per cent) were the suggestions offered by vegetable growers for marketing their produce in a better way.

\section{CONCLUSION}

The constraints such as fluctuation in market price, high commission charges, high cost of transportation, absence of storage facilities, lack of market information, Inadequate physical facilities in the market, prolonged transaction, faulty system of weighment, no grading facilities, illegal deduction while selling, lack of processing facilities and markets are far away are faced by the vegetable growers of the Palghar district and suggestions like providing access to market information, display of prices at each market place, fixing minimum price for the produce, fixing minimum labour charges, more procurement at nearby places, providing lodging and boarding facilities at market place, establishing separate market for major produce were provided to overcome the constraints faced. The extension agencies should consider these facts while planning and executing programmes for the vegetable growers of the Palghar district. 


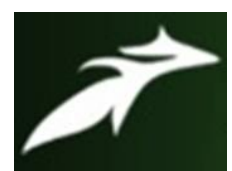

S.H. More et al, International Journal of Advances in Agricultural Science and Technology, Vol.8 Issue.1, January-2021, pg. 29-32

ISSN: 2348-1358

Impact Factor: 6.057

NAAS Rating: 3.77

\section{REFERENCES}

[1]. Chorge K.V., 2009. "Marketing behaviour of cashewnut growers in Konkan region". Ph.D. Thesis, Dr. Balasaheb Sawant Konkan Krishi Vidyapeeth, Dapoli.

[2]. Joshi A.M., 2012. "Marketing behaviour of Mango growers". Thesis, M.Sc. (Agri.), Dr. Balasaheb Sawant Konkan Krishi Vidyepeeth, Dapoli.

[3]. Ramasamy C., 1985. "Marketing of bhendi in Coimbatore district- An economic analysis". Madras Agriculture Journal. 72(2): 88-91 